\title{
TINDAK TUTUR ASERTIF DALAM INTERAKSI JUAL-BELI DI PASAR BETENG TRADE CENTER (BTC) LANTAI 2 DAN RELEVANSINYA SEBAGAI MATERI AJAR BAHASA INDONESIA DI SEKOLAH MENENGAH ATAS
}

\author{
Elvira Chustiana Khoiri ${ }^{1}$, Budhi Setiawan ${ }^{2}$, Muhammad Rohmadi ${ }^{3}$ \\ Universitas Sebelas Maret \\ E-mail : elvirachustiana@student.uns.ac.id ${ }^{1}$
}

\begin{abstract}
Abstrak : Penelitian ini bertujuan untuk mendeskripsikan (1) tindak tutur asertif menyatakan yang digunakan dalam interaksi jual-beli antara penjual dan pembeli di pasar BTC lantai 2 kota Surakarta; (2) bentuk implikatur dari tindak tutur asertif menyatakan yang digunakan dalam interaksi jual-beli antara penjual dan pembeli di pasar BTC lantai 2 kota Surakarta; (3) fungsi implikatur yang muncul dalam tindak tutur asertif menyatakan dalam interaksi jual-beli antara penjual dan pembeli di pasar BTC lantai 2 kota Surakarta; dan (4) relevansi tindak tutur asertif menyatakan dalam interaksi jual-beli antara penjual dan pembeli di pasar BTC lantai 2 sebagai bahan ajar teks negosiasi di Sekolah Menengah Atas. Penelitian ini menggunakan metode kualitatif dengan menggunakan pendekatan kajian pragmatik terkait tindak tutur. Hasil penelitian adalah sebagai berikut. Pertama, terdapat 35 variasi data tuturan yang terjadi dalam interaksi jualbeli antara penjual dan pembeli di pasar BTC lantai 2 kota Surakarta. Kedua, dari 35 tuturan asertif menyatakan dalam interaksi jual-beli yang dilakukan oleh penjual dan pembeli dikategorikan kedalam dua bentuk implikatur, yaitu konvensional dan nonkonvensional. Ketiga, dari 35 data tuturan dianalisis fungsi implikatur yang muncul dari masing-masing data tuturan dalam interaksi jual-beli antara penjual dan pembeli di pasar BTC lantai 2 kota Surakarta. Keempat, Tindak tutur asertif menyatakan dalam interaksi jual-beli yang muncul di pasar BTC lantai 2 dapat dipertimbangkan sebagai materi ajar teks negosiasi pada kompetensi dasar 3.11 mengkontruksi teks negosiasi untuk kelas X SMA. dengan mempertimbangkan variasi serta tujuan pembelajaran yang ingin dicapai.
\end{abstract}

Kata Kunci : Tindak tutur asertif, menyatakan, implikatur, teks negosiasi.

\section{ASSERTIVE SPEECH ACT IN SALE-BUY INTERACTION IN BETENG TRADE CENTER (BTC) 2nd Floor AND ITS RELEVANCE AS INDONESIAN TEACHING MATERIALS IN THE MIDDLE SCHOOLS}

\begin{abstract}
This study aims to describe (1) assertive speech acts stating what is used in buying and selling interactions between sellers and buyers in the second floor BTC market in the city of Surakarta; (2) the assertive form of assertive speech act stating that is used in buying and selling interactions between sellers and buyers in the second floor BTC market in the city of Surakarta; (3) the implicature function that appears in assertive speech acts states in the interaction of buying and selling between sellers and buyers in the second floor BTC market in the city of Surakarta; and (4) the relevance of assertive speech acts states in the interaction of buying and selling between sellers and buyers in the 2nd floor BTC market as teaching material for negotiating texts in high schools. This study used a qualitative method using a pragmatic study approach related to speech acts. The results of the study are as follows. First, there are 35 variations of speech data that occur in the interaction of buying and selling between sellers and buyers in the second floor
\end{abstract}

BASASTRA Jurnal Bahasa, Sastra, dan Pengajarannya

Volume 8 Nomor 2, Oktober 2020, P-ISSN 2302-6405, E-ISSN 2714-9765 
BTC market in the city of Surakarta. Second, from 35 assertive utterances stated in the interaction of buying and selling carried out by the seller and buyer are categorized into two forms of implicature, namely conventional and non-conventional. Third, from 35 speech data analyzed the implicature function that emerged from each speech data in the interaction of buying and selling between sellers and buyers in the second floor BTC market in Surakarta. Fourth, Assertive speech acts state that the buying and selling interactions that arise in the BTC market on the 2nd floor can be considered as negotiating text teaching material on basic competence 3.11 constructing negotiating texts for class X SMA by considering variations and learning objectives to be achieved.

Keyword : Assertive speech acts, states, implicature, negotiating text.

\section{PENDAHULUAN}

Bahasa sebagai alat komunikasi haruslah dipahami secara tepat oleh penutur maupun mitra tutur. Hal ini dimaksudkan agar tidak menimbulkan salah tafsir atau pengertian diantara keduanya. Dalam mencapai hal tersebut tidak hanya dibutuhkan pemahaman secara semantis saja, tetapi juga memiliki pemahaman pragmatis. Komunikasi dianggap berhasil apabila mitra tutur dapat menangkap maksud yang disampaikan penutur.

Pemakaian bahasa terjadi dihampir diseluruh bidang ataupun kegiatan. Misalnya, bidang pendidikan, kesehatan, keagamaan, politik, sosial, kebudayaan dan masih banyak lagi. Komunikasi dimasingmasing bidang tersebut memiliki kekhasannya tersendiri. Pembicaraan atau tuturan dalam suatu percakapan, yang dilakukan antara penutur dan lawan tutur dapat berbentuk tindak tutur langsung maupun tindak tutur tidak langsung. Dalam bidang ekonomi dan sosial, suatu percakapan dapat terjadi dalam situasi transaksi jual-beli melalui tawar-menawar, dalam hal ini pasar menjadi tempat yang potensial dalam mengkaji bahasa.
Pasar Beteng Trade Center (BTC) memiliki sistem transaksi jualbeli yang unik dalam bertutur antara penjual dan pembeli, khususnya lantai 2. Karena pasar ini memiliki populasi yang sangat padat dan luas, sehingga ruang lingkupnya dibatasi dengan berorientasi hanya pada beberapa kios atau toko yang berada di lantai 2 . Selain itu, pasar BTC merupakan pusat grosir pakaian terbesar di kota Surakarta, sehingga memungkinkan adanya intensitas yang tinggi antara penjual dan pembeli dalam terjadinya transaksi jual-beli dan tawar-menawar. Hal tersebut dapat memberikan varian dalam pembelajaran teks negosiasi, khususnya pada materi menkontruksi teks negosiasi.

Salah satu bentuk contoh tindak tutur yang terjadi dalam percakapan antara penjual dan pembeli yang ada di pasar Beteng Trade Center (BTC) lantai 2 kota Surakarta:

\begin{tabular}{|c|c|}
\hline Pembeli & $\begin{array}{l}: \text { Keep no 37A atas } \\
\text { nama Mawar. }\end{array}$ \\
\hline Penjual & $: \begin{array}{l}\text { Aira maxy biru. } \\
110.000\end{array}$ \\
\hline Pembeli & $\begin{array}{l}\text { : Vinka maxy dusty } \\
\text { masih kak? }\end{array}$ \\
\hline Penjual & : Full keep kak. \\
\hline Pembeli & $\begin{array}{l}\text { Rp. } 110.000 \\
\text { makasih. }\end{array}$ \\
\hline
\end{tabular}

BASASTRA Jurnal Bahasa, Sastra, dan Pengajarannya 
Penjual : Iya kak, sama-sama. terima kasih.

Contoh tersebut menandakan adanya ciri khusus dalam tuturan antara penjual dan pembeli yang selama interaksi jual-beli yang terjadi di pasar Beteng Trade Center (BTC) lantai 2 kota Surakarta.

Tempat transaksi jual-beli yang dipilih penulis sebagai kajian yang akan diteliti adalah pasar Beteng Trade Center (BTC) lantai 2 Kota Surakarta, pasar ini merupakan pasar khusus bagi reseller toko pakaian berbasis online. Pasar ini memiliki keunikan yang berbeda dengan pasar pada umumnya. Bila transaksi tawar-menawar dalam proses jual-beli yang dilakukan pedagang dan pembelinya pada pasar tradisional umunya terjadi secara langsung, pasar BTC melakukan transaksi tawar-menawar melalui media online. Sehingga, pasar hanya menjadi tempat menyelesaikan atau mengambil barang dengan sistem kode bocking. Pasar Beteng Trade Center (BTC) Kota Surakarta merupakan pasar sentral oleh-oleh kain dan pakaian untuk daerah Surakarta yang bertempat di pusat Kota Surakarta. Pasar ini beroprasi setiap Senin-Sabtu dari pukul 08.00-16.00 WIB, angka transaksi jual-beli di pasar BTC sangat tinggi dan selalu dipadati oleh penjual dan pembeli. Sehingga, pasar ini memunculkan fenomena bahasa tawarmenawar yang baru dan berbeda dengan pasar pada umumnya.

Berdasarkan rumusan masalah di atas, penelitian ini memiliki tujuan untuk mendeskripsikan: (1) bentuk tindak tutur asertif menyatakan yang terjadi dalam interaksi jual-beli di pasar Beteng Trade Center (BTC) Surakarta, (2) bentuk implikatur dalam tindak tutur asertif menyatakan yang terjadi dalam interaksi jual-beli di pasar Beteng Trade Center (BTC) Surakarta, (3) fungsi implikatur dalam tindak tutur asertif menyatakan yang terjadi dalam interaksi jual-beli di pasar Beteng Trade Center (BTC) Surakarta, (4) tindak tutur asertif yang terjadi dalam interaksi jual-beli di pasar Beteng Trade Center (BTC) Surakarta dan relevansinya terhadap pembelajaran di SMA.

Chaer \& Agustina (2004: 4950) menjelaskan bahwa tindak tutur (speech act) merupakan kemampuan berbahasa seseorang dalam menghadapi situasi tertentu. Tindak tutur ini bersifat psikologis dimana gejala individul yang muncul dari pihak penutur. Menurut Searle, tindak tutur juga (dalam Rohmadi, 2004:29). Searle (dalam Rohmadi, 2010:32) menjelaskan pengertian tindak tutur yang diartikan sebagai hasil atau produk dari suatu kalimat dalam kondisi tertentu dan merupakan satuan terkecil dari komunikasi linguistik yang dapat berwujud perintah, pertanyaan, pernyataan dan lain sebagainya.

Senada dengan pernyataan Chaer \& Agustina, Sulistyo (2013:6) membatasi pengertian tindak tutur sebagai kemampuan seseorang dalam menggunakan bahasa untuk menyampaikan maksud atau pesanpesan kepada mitra tutur. Karena tindak tutur merupakan suatu produk tindak verbal seseorang yang digunakan untuk menyampaikan maksud/tujuan kepada mitra tutur. Sehingga, sebuah percakapan dalam komunikasi tidak hanya berhenti pada makna dari kata saja, tetapi lebih menekankan pada pemahaman makna yang dikehendaki penuturnya.

$$
\text { Searle (dalam Leech, }
$$
2011:164) mengkasifikasikan tindak tutur menjadi lima, yaitu tindak tutur 
asertif, tindak tutur direktif, tindak tutur komisif, tindak tutur ekspresif, dan tindak tutur ekspresif. Pada penelitian ini, fungsi implikatur yang bersumber dari teori Searle difokuskan pada bentuk tindak tutur asertif.

Tindak tutur asertif (assertive) atau disebut juga sebagai tindak tutur refresentatif (refresentatives), merupakan ilokusi yang mengikat kebenaran pada apa yang diujarkan oleh penutur. Misalnya menyarankan, menuntut, menyatakan, membanggakan, mengeluh, memberitahu, dan melaporkan. Tindak tutur asertif berfungsi menjelaskan sesuatu seperti apa adanya atau menetapkan sesuatu sesuai dengan ujaran (apa yang dikatakan tidak memiliki maksud tersirat/tersembunyi). Sehingga, dari segi pembicaraan dari ujaran yang dikatakan sesuai dengan kebenaran proposisinya.

Menurut Grice (dalam Rusminto, 2009: 73) mengemukakan bahwa untuk mencapai suatu implikatur percakapan demi keberlangsungan komunikasi sesuai dengan yang diharapkan. Penutur dan mitra tutur harus menciptakan suatu pola kerja sama yang baik sebagai upaya dalam mengatur hak dan kewajibaan diantara keduanya. Pola kerja sama yang dimakudkan dikenal sebagai 'prinsip kerja sama.' Teori Grice mengenai implikatur percakapan menjelaskan bahwa penutur selalu bermaksud untuk bekerja sama ketika berbicara. Salah satu cara untuk menujukan suatu tindakan bekerja sama dilakukan dengan menyampaikan informasi yang diperlukan.

Setiap tindak tutur pada dasarnya mengimplikasikan sesuatu. Implikasi tersebut adalah maksud atau proposisi yang biasnya tersembunyi dibalik tuturan yang diucapkan; dan bukan merupakan bagian langsung dari tuturan tersebut (Parker, 1986:21; Wijana, 1996:37). Pada sebuah percakapan dimungkinkan muncul gejala dimana apa yang dituturkan berbeda dengan apa yang diimplikasikan. Sehubungan dengan hal tersebut, Wright (1975:379) menyatakan, "what is meant is not what is said."

Munculnya perbedaan antara "tuturan" dengan "implikasinya", terkadang dapat menyulitkan penutur untuk memahaminya. Namun pada umumnya, antara penutur dengan petutur sudah saling berbagi pengalaman dan pengetahuan, sehingga percakapan mampu mencapai keselarasan dan berjalan dengan komunikatif. Ilustrasi adanya implikatur percakapan tergambar sebagai berikut.

Teori implikatur berfungsi untuk membedakan antara suatu/hal yang dikatakan oleh seseorang sengan suatu/hal yang dimaksudkan oleh seseorang dalam sebuah uajaran. Sejalan dengan penjelasan Grice (dalam Grundy 2007: 9) bahwa Sebuah kalimat yang sama dalam sebuah pemahaman mitra tutur tidak mungkin memiliki makna yang berlawanan apabila mampu disampaikan secara jelas (eksplisit). Fenomena yang melatarbelakangi munculnya istilah implikatur adalah fenomena dalam dalam sebuah pertuturan, penutur dan mitra tutur diharuskan untuk mematuhi kaidahkaidah prinsip percakapan. Akan tetapi, dalam proses fenomena tersebut dimungkinkan adanya pelanggaran prinsip percakapan baik secara sengaja maupun tidak disengaja. 
Implikatur dengan demikian merujuk pada adanya perbedaan antara "apa yang diucapkan" dengan "apa yang diimpikasikan." Namun, perbedaan itu tidak menjadi faktor penghalang dalam memahami suatu percakapan karena pembicara sudah saling mengetahuinya. Oleh karena itu implikatur tidak perlu digunakan secara eksplisit (Wijana, 1996: 68). Masalah implikatur percakapan dianggap sebagai inti terpenting dalam pengkajian prgmatik (Levision, 1996:68). Alasanya karena masalah ini langsung berkaitan dengan penggunaan bahasa secara praktis, baik verbal maupun non-verbal (Edmondson, 1981:38).

Suatu proses pembelajaran tersusun atas suatu kombinasi yang meliputi unsur-unsur manusiawi, perlengkapan, fasilitas, material, dan prosedur yang saling berkaitan untuk mencapai tujuan pembelajaran. Tujuan kegiatan pembelajaran ialah suatu deskripsi mengenai tingkah laku yang diharapkan tercapai oleh siswa setelah berlangsungnya proses pembelajaran (Hamalik, 2013: 57).

Berdasarkan kurikulum 2013 menetapkan pada pembelajaran berbasis teks baik lisan maupun tulisan pada kompetensi dasar (KD) setiap materi pelajaran dalam silabus bahasa Indonesia, dapat berhubungan dengan kajian mengenai tindak tutur agar dapat memproduksi teks lisan maupun tulisan dengan lebih beragam tanpa mengurangi nilai baik dan benar pada sebuah sumber belajar. Pada penelitian ini direlevansikan dengan materi pembelajaran teks negosiasi sebagai teks terpilih sesuai dengan silabus bahasa Indonesia kelas X terdapat KD 4.11 Mengkontruksikan teks negosiasi dengan memperhatikan isi struktur (orientasi, penawaran, pengajuan, persetujuan, penutup) dan kebahasaan.

\section{METODE}

Penelitian ini dilaksanakan di pasar Beteng Trade Cenrter (BTC) khususnya di lantai 2 yang beralamat di Jalan Mayor Sunaryo, Kadung Lumbu, Kecamatan Pasar Kliwon, Kota Surakrta, Jawa Tengah 57133. Objek penelitian merupakan tuturan asertif dalam ineraksi jual-beli antara penjual dan pembeli yang terjadi di pasar BTC lantai 2. Metode penelitian yang digunakan adalah deskriptif kualitatif. Data yang ada berupa rekaman hasil observasi yang kemudian ditranskip melalui teknik simak, rekam, dan catat. Data pendukung lainnya merupakan hasil wawancara sederhana dengan narasumber terkait.

Penelitian tindak tutur ini merupakan jenis penelitian kualitatif dengan pendekatan kajian pragmatik (tindak tutur). Penelitian ini menggambarkan peristiwa yang terjadi pada saat dilakukannya penelitian, misalnya penelitian ini membahas tindak tutur asertif dalam interaksi jual-beli di BTC Surakarta, maka penggambaran dalam penelitian ini meliputi ruang lingkup tindak tutur asertif yang terjadi dalam interaksi jual-beli di Pasar Beteng Trade Center (BTC) Surakarta selama proses penelitian berlangsung. Dalam penelitian kualitatif kedudukan peneliti adalah sebagai pelaksana, perencana, pengumpul data, penganalisis, penafsir data, dan pelopor hasil penelitiannya.

Teknik yang digunakan adalah purposive sempling, yaitu sampel dipilih berdasarkan pertimbangan khusus atau memiliki kaitan tertentu berupa informasi mendalam mengenai 
permasalahan serta terlibat langsung dan dapat dipercaya untuk menjadi sumber data utama, maupun pendukung. Menurut Sugiyanto (2016:85) menyatakan bahwa purposive sampling adalah teknik pengambilan sample sumber data dengan pertimbangan tertentu. Purosive sampling berperan dalam menentukan jenis data yang dibutuhkan oleh peneliti, meliputi; berupa percakapan asertif menyatakan, sering digunakan atau muncul baik oleh penjual maupun pembeli, terjadi dalam interkasi jual-beli, serta terjadi di lokasi penelitian yaitu pasar BTC lantai 2.

\section{HASIL DAN PEMBAHASAN}

\section{Bentuk Tindak Tutur Asertif Menyatakan yang Terjadi dalam Interaksi Jual-Beli di Pasar Beteng Trade Center (BTC) Surakarta.}

Tindak tutur asertif menyatakan dalam penelitian ini mengacu pada teori Searle dan Austin (dalam Sudaryanto: 2001). Tuturan yang dimaksudkan dapat dijabarkan dalam berbagai konteks situasi yang terjadi di lantai dua pasar BTC. Tuturan antara penjual dan pembeli yang dianalisis terbagi menjadi dua situasi, yaitu secara langsung (bertatap muka antara penjual dan pembeli) serta melalui percakapan telefon (yang terjadi di lantai 2 pasar BTC). Tindak tutur yang dianalisis merupakan tindak tutur asertif menyatakan yang sering muncul atau digunakan dalam interaksi jual-beli antara penjual dan pembeli dan berpegang pada prinsip.

\begin{tabular}{clll}
\hline Tindak & Lokusi & \multicolumn{2}{l}{ Tindak-tutur } \\
Lokusi & Pernyataan & yang & apabila \\
& & diujarkan & dalam \\
& bentuk & berita \\
& dengan & tujuan \\
\hline
\end{tabular}

\begin{tabular}{lll}
\hline & $\begin{array}{l}\text { agar mendapat } \\
\text { kepercayaan } \\
\text { pendengar }\end{array}$ \\
\hline Tindak & Ilokusi & \multicolumn{2}{l}{ Tindak-tutur } \\
Ilokusi & asertif & yang apabila \\
& diujarkan maka \\
& mewakili \\
& kebenaran \\
& proposisi yang \\
& diekspresikannya. \\
\hline
\end{tabular}

(a) Pembeli : Delima maxy mbak, satu dusty, dua tosca.

(b) Penjual : Sudah keep belum?

(c) Pembeli : Belum

(d) Penjual : Karena ambil tiga, tak kurangi lima ribu kaya biasanya.

(e) Pembeli : Jadinya berapa, mbak?

(f) Penjual : 115 kali 3 kurangi lima ribu. tiga puluh empat ribu. Sumber: (D-1/TTA/ PPBTC/ tahun 2020).

Situasi pada tuturan tuturan antara penjual dan pembeli di atas merupakan peristiwa yang terjadi ketika proses interaksi antara penjual dan pembeli di salah satu toko lantai 2 pasar BTC Surakarta. Pembeli menggunakan tindak tutur asertif menyatakan. Tindak tutur ini dinyatakan untuk mengujarkan atau memberitahu tentang isi pikiran atau hati penutur tentang suatu informasi.

Berdasarkan konteks tuturan pada data (a) merupakan tindak tutur asertif menyatakan dan memesan. Ada maksud agar lawan tutur bereaksi atau melakukan suatu tindakan dari apa yang dituturkan oleh pembeli (mengambilkan produk sesuai yang pembeli tuturkan). Sedangkan tindak tutur asertif menyatakan dan bertanya diujarkan oleh penjual melalui tuturan data (b) dan tuturan data (e) oleh pembeli. Tuturan pada data (c) 
merupakan bentuk pernyataan berupa jawaban.

Berdasarkan teks, koteks, dan konteks pada tuturan pada di atas yang diujarkan oleh penjual ditandai dengan nada bertanya, dan dibuktikan melalui respon lawan tutur (pembeli) terhadap ujaran yang dituturkan penjual. Tindak tutur asertif menyatakan kesepakatan tampak pada kalimat yang diujarkan oleh penjual pada tuturan data (d) dan (f). Sementara itu, tuturan pada data (e) merupakan

Berdasarkan penjelasan dan analisis data di atas maka dapat ditegaskan bahwa tindak tutur asertif menyatakan dilakukan oleh pembeli berfungsi untuk menyatakan produk yang diinginkan, sedangkan tindak tutur asertif yang dilakukan oleh penjual berfungsi meyakinkan dan menyenagkan pembeli melalui potongan harga yang ditawarkan agar terpengaruh.

(a) Pembeli : Nagita set mustard masih kak?

(b) Penjual : Habis kak.

(c) Pembeli : Kudu jalan-jalan, biar bisa nemu kalau udah kehabisan begini.

(d) Penjual : Coba toko satu kak.

(e) Pembeli : Makasih kak.

Sumber: (D-2/TTA/ PPBTC/ tahun 2020).

Situasi pada tuturan tuturan antara penjual dan pembeli di atas dapat dideskripsikan bahwa penjual dan pembeli sedang melakukan suatu proses interkasi jual-beli. Pembeli menggunakan tindak tutur asertif menyatakan. Tindak tutur ini merupakan tindak tutur yang menyatakan isi pikiran maupun isi hati penutur melalui ujaran yang dituturkan. Berdasarkan konteks tuturan pada data (a) merupakan tuturan menyatakan dengan maksud bertanya. Sedangkan tuturan pada data (b) merupakan bentuk menyatakan sebagai jawaban.

Tuturan data (c) merupakan tindak tutur asertif menyatakan kritik berupa keluhan, hal tersebut ditunjukan melalui nada penutur dalam mengujarkan tuturan serta fakta bahwa produk yang diinginkan pembeli tidak tersedia. Sedangkan pada tuturan yang disampaikan oleh penjual pada tuturan data (d) berdasarkan teks, koteks, dan konteks pada data di atas merupakan tindak tutur asertif menyatakan dan saran. Hal ini diwujudkan melalui kata "Coba" dimana penutur memberikan pilihan kepada lawan tutur (pembeli).

Berdasarkan penjelasan dan analisis data di atas maka dapat ditegaskan bahwa tindak tutur asertif menyatakan dilakukan oleh pembeli berfungsi untuk mengungkapkan isi hatinya terkait suatu hal, sedangkan tindak tutur asertif menyatakan oleh penjual berfungsi untuk mendapatkan daya tarik dari pembeli melalui saran yang diujarkan.

(a) Pembeli : Salida marun dua, Raline dusty, Andin biru, sama Nada.

(b) Penjual : (mengambil beberapa produk) Apa lagi?

(c) Pembeli : Eh Andine yang dusty, Raline biru. nada biru, eh bentar mbak.

(d) Penjual : Maem disik, mbak.

(e) Pembeli : Saking kekebaken iki mbak.

Sumber: (D-3 TTA/ PPBTC/ tahun 2020).

Situasi pada tuturan antara penjual dan pembeli di atas dapat dilihat bahwa sedang terjadi interaksi jual-beli antara penjual dan pembeli menggunakan tindak tutur asertif menyatakan. Tindak tutur asertif 
menyatakan ini merupakan tindak tutur yang berfungsi untuk menyatakan isi pikiran atau isi hati sang penutur baik dengan tujuan menginformasikan sesuatu atau mengambarkan keadaan yang ada. Berdasarkan konteks pada tuturan yang diujarkan oleh pembeli melalui data (a) merupakan tuturan asertif menyatakan yang mengandung maksud sebagai perintah, hal tersebut didukung dengan cara penjual merespon tuturan pada data (b).

Tuturan pada data (c) merupakan tindak tutur asertif menyatakan penundaan. Hal tersebut ditunjukan melalui, "eh bentar mbak," pada pengalan kalimat yang disebabkan adanya kesalahan menurut sang penutur sehingga terjadi penundaan. Sedangkan berdasarkan teks, koteks, dan konteks pada tuturan di atas terdapat tuturan pada data (d) terdapat tindak tutur asertif menyatakan dan sindiran. Hal tersebut dapat dilihat dari intonasi dan ekspresi yang digunakan oleh penutur (penjual) saat mengujarkan tuturan. Berbeda dengan tuturan pada tuturan data (e) yang diutarakan oleh pembeli terdapat tindak tutur asertif menyatakan menyangkal.

Berdasarkan penjelasan dan analisis data tuturan di atas maka dapat ditegaskan bahwa tindak tutur asertif menyatakan dilakukan oleh pembeli untuk mengungkapkan sekaligus mengkoreksi kesalahan melalui penundaan dari apa yang telah dituturkan, dan pada tuturan asertif menyaatakan menyangkal juga digunakan sebagai koreksi pada jawaban lawan tutur (penjual), sedangkan tindak tutur asertif menyatakan yang diujarkan oleh penjual memiliki fungsi sebagai saran yang diujarkan melalui sindiran agar pembeli lebih fokus atau kembali fokus.

(a) Pembeli : Julia tunik biru sama Samira dusty.

(b) Penjual : Sudah keep?

(c) Pembeli : Belum.

(d) Penjual : Samira ada, Julia full keep.

(e) Pembeli : Yah tulung, dah TF mas castemerku.

(f) Penjual : Ora iso, ngko sore isone bar bongkaran.

Sumber: (D-4/TTA/ PPBTC/

tahun 2020).

Situasi pada tuturan antara penjual dan pembeli di atas, penjual dan pembeli menggunakan tindak tutur asertif menyatakan dalam proses interaksi jual-beli. Tindak tutur asertif menyatakan merupakan tindak tutur yang berfungsi untuk mengungkapkan isi pikiran atau isi hati sang penutur terkait suatu informasi ataupun suatu hal. Berdasarkan konteks pada tuturan yang diiujarkan oleh pembeli melalui tuturan data (d) merupakan tuturan asertif menyatakan dengan maksud memberitahu keadaan sebenarnya, sementara tuturan data (e) yang diujarkan pembeli merupakan tindak tutur asertif menyatakan dan memohon. Hal tersebut dapat dilihat melalui penekanan intonasi pada kata "Yah tulung," yang diujarkan oleh pembeli untuk mendapat simpati penjual.

Sedangkan tindak tutur asertif menyatakan yang diujarkan oleh penjual melalui tuturan data (f) berdasarkan teks, koteks, dan konteks pada data 4 terdapat tindak tutur asertif menyatakan larangan. Hal tersebut ditandai dengan pengalan kaliamt, "Ora iso," dan diiringi saran dari penjual melalui pengalan kalimat, "Ngko sore isone," untuk menyatakan kesepakatan yang dapat dibuat oleh 
penjual dan pembeli di waktu yang akan datang.

Berdasarkan penjelasan dan analisis data tuturan di atas maka dapat ditegaskan bahwa tindak tutur asertif menyatakan dilakukan oleh pembeli untuk meyakinkan penjual dengan cara mengajukan permohonan, sedangkan tindak tutur asertif menyatakan yang dilakukan oleh penjual berfungsi sebagai penolakan atas permohonan yang diajukan oleh pembeli.

(a) Pembeli : Batiknya bahan apa buk ini?

(b) Penjual : Ini katun tapi kualitas premium buk, jadi lembut dan tebal.

(c) Pembeli : Tapi ini kok warnanya samar gini ya bu? nanti dicuci gimana?

(d) Penjual : Ini dicuci tidak apaapa buk, karena ini dalemnya tidak luntur.

(e) Pembeli : Ambil Satu bu.

(f) Penjual : Ambil Tiga, yang satu saya kasih setengah harga bu.

(g) Pembeli : Satu aja. Sumber: (D-5/TTA/ PPBTC/ tahun 2020).

Situasi pada tuturan antara penjual dan pembeli di atas, dapat diketahui bahwa tindak tutur asertif menyatakan digunakan oleh penjual dan pembeli dalam proses transaksi jual-beli. Tindak tutur asertif menyatakan merupakan tutran yang menyatakan suatu informasi kepada orang lain tentang segala sesuatu terkait informasi. Berdasarkan konteks tuturan yang diujarkan oleh pembeli pada tuturan data (b) merupakan tindak tutur menyatakan yang berisi penjelasan atau deskripsi yang ingin diutarakan oleh penjual sesuati dengan tuturan bertanya oleh pembeli pada data (a).
Tuturan data (c) merupakan tindak tutur asertif introgatif dan menyatakan keluhan, ditandai dengan kalimat bernada tanya dan penekanan pada "kok warnanya samar gini ya buk" yang menunjukan ketidakpuasan pembeli. Sedangkan tindak tutur asertif menyatakan berdasarkan teks, koteks, dan konteks pada data di atas dapat dilihat pada data (f) melalui kalimat "Ambil tiga," merupakan tindak tutur asertif ajakan yang menyatakan daya tariknya pada, "...yang satu saya kasih setengah harga bu."

Berdasarkan penjelasan dan analisis data di atas maka dapat ditegaskan bahwa tindak tutur asertif menyatakan dilakukan oleh pembeli untuk meminta ketegasan, sedangkan tindak tutur asertif menyatakan yang dilakukan oleh penjual berfungsi untuk meyakinkan dan mempengaruhi pembeli.

Berdasarkan hasil identifikasi semua data dalam penelitian ini, untuk tindak tutur asertif menyatakan tersebut rata-rata digunakan oleh penjual dan pembeli dalam interaksi jual-beli di Pasar BTC lantai 2. Dengan demikian, tindak tutur asertif menyatakan memiliki komunikatif yang sangat penting dalam bernegosiasi berdasarkan teks, koteks, dan konteks pragmatik.

\section{Bentuk Implikatur dalam Tindak Tutur Asertif Menyatakan yang Terjadi dalam Interaksi Jual-Beli di Pasar Beteng Trade Center (BTC) Surakarta.}

Implikatur konvensional memiliki pengertian sebagai implikatur yang bersifat umum atau konvensional. Setiap orang pada umumnya memiliki kemampuan dalam memahami sebuah maksud atau 
implikatur dari suatu hal tertentu. Apabila implikatur konvensional bersifat umum, maka implikatur percakapan bersifat kebalikanya atau non-konvensional (maksudnya sesuatu yang diimplikasikan tidak mempunyai hubungan langsung dengan tuturan yang diucapkan).

Implikatur nonkonvensional atau disebut juga implikatur percakapan merupakan implikasi pragmatis yang secara tersirat terdapat dalam suatu ujaran percakapan. Implikatur nonkonvensional memiliki makna atau pengertian yang beragam tergantung pada penafsiran penutur dan lawan tutur. Artinya, pemahaman terhadap "yang dimaksudkan" sangat bergantung pada konteks dalam percakapan (speech act).

(a) Pembeli : Delima maxy mbak, satu dusty, dua tosca.

(b) Penjual : Sudah keep belum?

(c) Pembeli : Belum

(d) Penjual : Karena ambil tiga, tak kurangi lima ribu kaya biasanya.

(e) Pembeli : Jadinya berapa, mbak?

(f) Penjual : 115 kali 3 kurangi lima ribu. tiga puluh empat ribu.

Sumber: (D-1/TTA/ PPBTC/ tahun 2020).

Berdasarkan teks, koteks, dan konteks tuturan antara penjual dan pembeli pada data di atas terjadi di salah satu toko, dimana setiap toko di pasar BTC memberlakukan potongan pembelian bagi pembeli yang membeli barang sebanyak tiga produk atau lebih. Biasanya harga akan dipotong lima sampai sepuluh ribu rupiah, tergantung kebijakan pada setiap toko berbeda-beda. Ada yang dengan cara memberikan potongan harga apabila membeli produk lebih dari tiga item, ada pula yang memberlakukan dengan menukar nota pembelian untuk mendapatkan potongan harga. Pembeli baru saja membeli barang sejumlah tiga produk, sehingga pembeli mendapat potongan harga sebanyak lima ribu rupiah dari penjual saat melakukan pembayaran.

Berdasarkan penjelasan dan analisis data di atas maka dapat ditegaskan bahwa tindak tutur asertif menyatakan yang dilakukan oleh pembeli dan penjual merupakan jenis implikatur nonkonvensional, karena dalam tuturan terkait pembelian potongan dalam interaksi jual-beli hanya dipahami oleh penjual dan pembeli sebagai lingkungan tindak tutur terjadi.

(a) Pembeli : Nagita set mustard masih kak?

(b) Penjual : Habis kak.

(c) Pembeli : Kudu jalan-jalan, biar bisa nemu kalau udah kehabisan begini.

(d) Penjual : Coba toko satu kak.

(e) Pembeli : Makasih kak. Sumber: (D-2/ TTA/ PPBTC/ tahun 2020).

Berdasarkan teks, koteks, dan konteks tuturan antara penjual dan pembeli pada data 2 di atas terjadi di salah satu toko, dimana pasar BTC lantai di atas memiliki lebih dari 100 toko yang menjual pakaian dengan jenis dan model yang hampir semua toko memiliki keseragaman produk. Sehingga, apabila pembeli kehabisan produk A di toko Mawar, pembeli bisa menemukan produk A yang sama di toko Melati. Namun tak jarang produk A tersebut dijual dengan nama berbeda di setiap toko.

Berdasarkan penjelasan dan analisis data di atas maka dapat ditegaskan bahwa tindak tutur asertif menyatakan yang dilakukan oleh pembeli dan penjual merupakan jenis 
implikatur nonkonvensional, karena dalam tuturan terkait tetang upaya yang harus dia lakukan untuk mendapatkan produk yang sama dengan berkeliling berbagai toko yang ada di lantai dua saat kehabisan produk hanya dipahami oleh pembeli sebagai penutur dan penjual sebagai lawan tutur.

(a) Pembeli : Salida marun dua, Raline dusty, Andin biru, sama Nada.

(b) Penjual : (mengambil beberapa produk) Apa lagi?

(c) Pembeli : Eh Andine yang dusty, Raline biru. nada biru, eh bentar mbak.

(d) Penjual : Maem disik, mbak.

(e) Pembeli : Saking kekebaken iki mbak.

Sumber: (D-3 TTA/ PPBTC/ tahun 2020).

Berdasarkan teks, koteks, dan konteks tuturan antara penjual dan pembeli pada data di atas di atas terjadi di salah satu toko, dimana pada saat melakukan transaksi seorang pembeli terlihat tidak fokus karena banyak dan beragamnya produk yang dia beli. Pembeli salah menyebutkan nama produk beberapa kali, sehingga penjual menegurnya dengan nada bercanda yang kemudian ikut ditimpali dengan candaan oleh pembeli.

Berdasarkan penjelasan dan analisis data di atas maka dapat ditegaskan bahwa tindak tutur asertif menyatakan yang dilakukan oleh pembeli dan penjual merupakan jenis implikatur nonkonvensional, karena dalam tuturan terkait lelucon sebagai bahan bercanda hanya dipahami oleh penutur dan lawan tuturnya, pada situasi ini yaitu penjual dan pembeli.

(a) Pembeli : Julia tunik biru sama Samira dusty. (b) Penjual : Sudah keep?

(c) Pembeli : Belum.

(d) Penjual : Samira ada, Julia full keep.

(e) Pembeli : Yah tulung, dah TF mas castemerku.

(f) Penjual : Ora iso, ngko sore isone bar bongkaran.

Sumber: (D-4/TTA/ PPBTC/ tahun 2020).

Berdasarkan teks, koteks, dan konteks tuturan antara penjual dan pembeli pada data di atas di atas terjadi di salah satu toko, dimana pasar BTC merupakan pasar yang memiliki keunikan didalam metode jual-beli. Menggunakan sistem keep serta jualbeli berbasis online yang sebelumnya telah dilakukan antara penjual dan pembeli. Pasar menjadi tempat penyelesaian transaksi berupa pengambilan barang dan melakukan pembayaran. Untuk barang yang sudah di-keep sebelumnya, tetapi pembeli tidak menyelesaikan transaksi maka barang yang sudah di-keep dianggap batal dan akan ditawarkan pada pembeli lain. Tuturan terjadi saat pembeli ingin membeli suatu produk tetapi barang tersebut sudah full keep, sehingga dia harus menunggu sampai pukul 14.00 (batas waktu penyelesaian transaksi) dan memastikan ada barang yang mengalami batal keep).

Berdasarkan penjelasan dan analisis data di atas maka dapat ditegaskan bahwa tindak tutur asertif menyatakan yang dilakukan oleh pembeli dan penjual merupakan jenis implikatur konvensional, karena dalam tuturan terkait sistem bongkaran yang berlaku di pasar BTC telah dipahami, disepakati, dan digunakan dalam waktu yang sangat lama dilingkungan pasar BTC.

(a) Pembeli : Batiknya bahan apa buk ini? 
(b) Penjual : Ini katun tapi kualitas premium buk, jadi lembut dan tebal.

(c) Pembeli : Tapi ini kok warnanya samar gini ya bu? nanti dicuci gimana?

(d) Penjual : Ini dicuci tidak apaapa buk, karena ini dalemnya tidak luntur.

(e) Pembeli : Ambil Satu bu.

(f) Penjual : Ambil Tiga, yang satu saya kasih setengah harga bu.

(g) Pembeli : Satu aja.

Sumber: (D-5/TTA/ PPBTC/ tahun 2020).

Berdasarkan teks, koteks, dan konteks tuturan antara penjual dan pembeli pada data di atas di atas terjadi di salah satu toko, dimana seorang pembeli hendak membeli produk baju batik. Tetapi, pembeli tidak begitu paham mengenai dasar suatu produk, seperti jenis kain, cara perawatan, makna pada motif, dan sebagainya. Tampak penjual berusaha menjelaskan atau mendeskripsikan suatu produk berupa baju batik kepada pembeli terkait perawatan, cara mencuci dan kualitas.

Berdasarkan penjelasan dan analisis data di atas maka dapat ditegaskan bahwa tindak tutur asertif menyatakan yang dilakukan oleh pembeli dan penjual merupakan jenis implikatur nonkonvensional, karena dalam tuturan terkait produk batik yang sedang dibicarakan hanya dipahami oleh penutur dan lawan tuturnya, pada situasi ini yaitu penjual dan pembeli.

Fungsi Implikatur dalam Tindak Tutur Asertif Menyatakan yang Terjadi dalam Interaksi Jual-Beli di Pasar Beteng Trade Center (BTC) Surakarta.

Konsep mengenai implikatur dalam studi pragmatik memiliki setidaknya empat fungsi (kegunaan), diantaranya: (1) memungkinkan diperolehnya penjelasan fungsional yang bermakna terhadap fakta-fakta kebahasaan yang tidak terjangkau dalam teori-teori linguistik (deskriptif), (2) menjelaskan dengan eksplisit dan tegas tentang bagaimana kemungkinanya, bahwa pemakai bahasa dapat menangkap implikasi/pesan; meskipun apa yang diucapkan seeara lahiriah tidak sama dengan apa yang dimaksudkan, (3) meskipun klausa-klausa dihubungkan dengan kata-kata struktur yang sama, pada pemberian semantiknya dapat menyederhanakan perbedaan hubungan antara klausa, dan (4) berbagai macam fakta atau gejala kebahasaan dapat diterangkan secara lahiriah meskipun tidak memiliki kaitan bahkan bertentangan.

Fungsi implikatur dalam analisis data tindak tutur asertif menyatakan yang dilakukan baik penjual maupun pembeli memiliki fungsi yang beragam tergantung pada kebutuhan atau maksud dari ujaran, diantaranya; mengeluh, memerintah, membujuk, memberitahu, dan sebagainya.

(a) Pembeli : Delima maxy mbak, satu dusty, dua tosca.

(b) Penjual : Sudah keep belum?

(c) Pembeli : Belum

(d) Penjual : Karena ambil tiga, tak kurangi lima ribu kaya biasanya.

(e) Pembeli : Jadinya berapa, mbak?

(f) Penjual : 115 kali 3 kurangi lima ribu. tiga puluh empat ribu. Sumber: (D-1/TTA/ PPBTC/ tahun 2020). Berdasarkan penjelasan dan analisis data di atas bahwa tindak tutur asertif menyatakan dilakukan oleh pembeli berfungsi untuk menyatakan 
produk yang diinginkan, serta memiliki fungsi implikatur perintah. Pembeli menyatakan barang yang telah dipesan sebelumnya dengan maksud agara penjual melayani atau mengambilkan produk yang telah disebutkan.

Sedangkan tindak tutur asertif yang dilakukan oleh penjual berfungsi meyakinkan dan menyenagkan pembeli melalui potongan harga yang ditawarkan agar terpengaruh. Tuturan yang diujarkan penjual tersebut memiliki fungsi implikatur deklaratif, penjual bermaksud memberikan potongan harga sebagai bonus untuk pembeli yang sudah membei tiga produk sekalihgus.

(a) Pembeli : Nagita set mustard masih kak?

(b) Penjual : Habis kak.

(c) Pembeli : Kudu jalan-jalan, biar bisa nemu kalau udah kehabisan begini.

(d) Penjual : Coba toko satu kak.

(e) Pembeli : Makasih kak.

Sumber: (D-2/TTA/ PPBTC/ tahun 2020).

Berdasarkan penjelasan dan analisis data di atas bahwa tindak tutur asertif menyatakan dilakukan oleh pembeli berfungsi untuk mengungkapkan isi hatinya terkait suatu hal, serta memiliki fungsi implikatur sindiran. Hal tersebut dilakukan pembeli untuk mengungkapkan kekecewaanya pada penjual karena pembeli tidak mendapat produk yang diinginka, sehingga pembeli mengeluh dengan maksud menyindir penjual agar merasa bersalah.

Sedangkan tindak tutur asertif menyatakan oleh penjual berfungsi untuk mendapatkan daya tarik dari pembeli melalui saran yang diujarkan. Tuturan yang diujarkan penjual tersebut memiliki fungsi implikatur perintah, penjual bermaksud menyuruh atau meminta agar pembeli pergi ke cabang toko untuk melihat stok yang tersedia disana.

(a) Pembeli : Salida marun dua, Raline dusty, Andin biru, sama Nada.

(b) Penjual : (mengambil beberapa produk) Apa lagi?

(c) Pembeli : Eh Andine yang dusty, Raline biru. nada biru, eh bentar mbak.

(d) Penjual : Maem disik, mbak.

(e) Pembeli : Saking kekebaken iki mbak.

Sumber: (D-3 TTA/ PPBTC/ tahun 2020).

Berdasarkan penjelasan dan analisis data di atas bahwa tindak tutur asertif menyatakan dilakukan oleh pembeli untuk mengungkapkan sekaligus mengkoreksi kesalahan melalui penundaan dari apa yang telah dituturkan, dan pada tuturan asertif menyaatakan menyangkal juga digunakan sebagai koreksi pada jawaban lawan tutur (penjual), serta dalam tuturan pembeli memiliki fungsi implikatur perintah. Hal tersebut dilakukan pembeli untuk meminta agar penjual mengambilkan barang yang telah diujarkan.

Sedangkan tindak tutur asertif menyatakan yang diujarkan oleh penjual memiliki fungsi sebagai saran yang diujarkan melalui sindiran agar pembeli lebih fokus atau kembali fokus. Tuturan yang diujarkan penjual tersebut memiliki fungsi implikatur sindiran, penjual bermaksud menyindir pembeli yang selalu salah dalam menyebutkan nama produk yang telah dipesan dengan cara tidak menyakiti perasaan pembeli.

(a) Pembeli : Julia tunik biru sama Samira dusty. 
(b) Penjual : Sudah keep?

(c) Pembeli : Belum.

(d) Penjual : Samira ada, Julia full keep.

(e) Pembeli : Yah tulung, dah TF mas castemerku.

(f) Penjual : Ora iso, ngko sore isone bar bongkaran.

Sumber: (D-4/TTA/ PPBTC/ tahun 2020).

Berdasarkan penjelasan dan analisis data di atas bahwa tindak tutur asertif menyatakan dilakukan oleh pembeli untuk meyakinkan penjual dengan cara mengajukan permohonan, serta memiliki fungsi implikatur membujuk. Hal tersebut dilakukan oleh pembeli untuk membujuk penjual agar mau menjual produk tersebut padanya.

Sedangkan tindak tutur asertif menyatakan yang dilakukan oleh penjual berfungsi sebagai penolakan atas permohonan yang diajukan oleh pembeli. Tuturan yang diujarkan penjual tersebut memiliki fungsi implikatur memberitahu, penjual bermaksud memberitahu bahwa pembeli dapat kembali memeriksa produk pada waktu bongkaran.

(a) Pembeli : Batiknya bahan apa buk ini?

(b) Penjual : Ini katun tapi kualitas premium buk, jadi lembut dan tebal.

(c) Pembeli : Tapi ini kok warnanya samar gini ya bu? nanti dicuci gimana?

(d) Penjual : Ini dicuci tidak apaapa buk, karena ini dalemnya tidak luntur.

(e) Pembeli : Ambil Satu bu.

(f) Penjual : Ambil Tiga, yang satu saya kasih setengah harga bu.

(g) Pembeli : Satu aja.

Sumber: (D-5/TTA/ PPBTC/ tahun 2020).
Berdasarkan penjelasan dan analisis data di atas bahwa tindak tutur asertif menyatakan dilakukan oleh pembeli untuk meminta ketegasan, serta memiliki fungsi implikatur berspekulasi. Hal tersebut dimaksudkan pembeli untuk mendapatkan keyakinan dari penjual terkait keterangan yang dibutuhkan pembeli.

Sedangkan tindak tutur asertif menyatakan yang dilakukan oleh penjual berfungsi untuk meyakinkan dan mempengaruhi pembeli. Tuturan yang diujarkan penjual tersebut memiliki fungsi implikatur memberitahu, penjual bermaksud memberitahu pembeli terkait bahan, kualitas dan keunggulan dari produk batik yang tengah ditawarkan pada penjual.

Tindak Tutur Asertif yang Terjadi dalam Interaksi Jual-Beli di Pasar Beteng Trade Center (BTC) Surakarta dan Relevansinya terhadap Pembelajaran di SMA.

Hasil penelitian tindak tutur asertif dalam interaksi jual-beli yang digunakan oleh penjual dan pembeli melalui komunikasi lisan di Pasar Beteng Trande Center (BTC) lantai 2 tersebut dijadikan sebagai bahan pembelajaran untuk meningkatkan kemampuan mengkontruksi teks negosiasi menyesuaikan kompetensi dasar yang terdapat dalam silabus, serta menambah pemahaman dan kemampuan siswa terkait menumbuhkan minat dan jiwa bisnis kewirausahaan. Kompetensi dasar yang sesuai dengan penelitian ini adalah 3.11. mengkontruksikan teks negosiasi dengan memperhatikan isi struktur (orientasi, penawaran, pengajuan, persetujuan, penutup) dan kebahasaan. 
Tujuan pembelajaran untuk meningkatkan kemampuan mengkontruksikan teks negosiasi dengan memperhatikan isi struktur dan kebahasaan melalui media rekaman tindak tutur asertif dalam interaksi jual-beli di pasar Beteng Trade Center (BTC) lantai 2 sebagai bahan pembelajaran, dipaparkan dalam uraian di bawah ini.

(1) Mengenalkan pada siswa variasi teks negosiais sebagai sumber belajar dengan tetap memperhatikan realita sesungguhnya.

(2) Mengenalkan pada siswa peristiwa jual-beli yang digunakan oleh penjual dan pembeli Pasar Beteng Trade Center (BTC) lantai 2 dalam upaya mencapai kesepakatan.

(3) Mengenalkan kategori atau jenis-jenis tindak tutur dan implikatur.

(4) Mengenalkan kategori atau jenis-jenis tindak tutur dan implikatur kepada siswa dengan rekaman interaksi dalam jual-beli di Pasar Beteng Trade Center (BTC) lantai 2 Kota Surakarta.

(5) Memberi contoh serta memotifasi siswa agar mampu meningkatkan kemampuan mengkontruksi teks negosiasi dan memberikan pengalaman bernegosiasi baik di lingkungan siswa atau di masyarakat sehingga dapat menumbuhkan jiwa bisnis atau berwirausaha.

(6) Mengembangkan landasan berpikir siswa dan rasa cinta atau senang dalam menggali rasa ingin tahu terkait keberagaman jenis teks, terutama teks negosiasi.
(7) Membentuk kesadaran siswa tentang pentingnya tindak tutur yang diterapkan pada saat bernegosiasi, khususnya dalam penerapan bahasa yang baik dan efektif dalam teks negosiasi dan bernegosiasi.

(8) Menumbuhkan jiwa bisnis, dan membekali siswa dalam keterampilan untuk berbisnis atau berwirausaha.

Dalam pembelajaran untuk meningkatkan kemampuan bernegosiasi, bahan atau materi pembelajaran yang digunakan, yaitu (1) rekaman video interaksi jual-beli di Pasar Beteng Trade Center (BTC) lantai 2 Kota Surakarta, (2) buku teks Pragmatik karangan George Yule, (3) buku Prinsip-prinsip Pragmatik karangan George Leech (4) buku teks pengajaran Pragmatik karangan Henry Guntur Tarigan, dan (5) buku teks pegangan siswa kelas X SMA.

Mengkontruksi teks yaitu menjelaskan lebih detail kata demi kata. Sehingga, mengkotruksi teks negosiasi berarti menyusun teks negosiasi lisan dalam bentuk dialog serta menyusun teks negosiasi lisan dalam bentuk narasi. Oleh karena itu, pembelajaran untuk meningkatkan kemampuan pemahaman mengkontruksi teks negosiasi dengan menerapkan teori mengenai tindak tutur dan implikatur perlu diterapkan pada siswa di tingkat SMA, sesuai dengan kompetensi dasar yang ada dalam kurikulum dan silabus. Sejalan dengan fokus penelitian ini, yaitu KD 3.11 dan 4.11 pada siswa kelas X.

\section{SIMPULAN}

Fokus dalam penelitian ini mengkaji pada tindak tutur asertif menyatakan dengan memperhatikan bentuk dan fungsi implikatur yang 
melekat dalam tuturannya. Tindak tutur asertif menyatakan memiliki fungsi yang menyertai serta mengandung implikatur yang berfungsi, diantaranya; memberitahu, memesan, mengkritik, menyindir, memohon, melarang, mengeluh, mengajak, mengklaim, mengkoreksi, menawar, memohon, membujuk, meminta, menyarankan, meyakinkan, menyetujui, bertanya, dan perintah. Setiap fungsi yang menyertai tindak tutur asertif menyatakan baik yang diujarkan pembeli maupun penjual disesuaikan dengan tujuan dan maksud tuturan.

Berdasarkan hasil analisis data dan wawancara sederhana dengan narasumber guru mata pelajaran pendidikan bahasa Indonesia. Tindak tutur asertif dalam interaksi jual-beli di pasar BTC lantai 2 dapat dipertimbangkan sebagai bahan ajar pada teks negosiasi, khususnya KD 3.11 mengkontruksi teks negosiasi. Penjabaran pada analisis data menambah varian contoh atau gambaran teks negosiasi dengan membawa pengalaman kenyataan sehari-hari di tengah masyarakat bagi para siswa.

Berdasarkan hasil kajian dan simpulan dalam penelitian ini, peneliti mengajukan saran sebagai berikut. Pertama, dalam menciptakan materi ajar yang bervariasi dapat dilakukan dengan cara melibatkan siswa untuk berperan aktif mencari bahan pembelajaran, penerapan metode pembelajaran yang tepat, serta pelaksanaan pembelajaranyang tidak hanya berorientasi pada ruang kelas saja, tetapi melibatkan lingkungan masyarakat. Kedua, Penelitian berbasis ilmu pragmatik menjadi sebagian kecil topik yang dipilih atau diambil untuk dilakukan dalam studi
penelitian.Sehingga diperlukan perhatian lebih utamanya agar mahasiswa lebih aktif dalam berpartisipasi meningkatkan penelitian di bidang pragmatik. Ketiga, Penelitian yang penulis lakukan dapat dijadikan sumber ajar maupun diaplikasikan sebagai salah satu pemvariasian dengan tujuan meningkatkan kemampuan dan pemahaman teks negosiasi.

\section{REFERENSI}

Chaer, A dan Agustin. (2004). Sosiolinguistik: Perkenalan Awal. Jakarta: Rineka Cipta.

Grundy, P. (2007). Doing pragmatics. Second edition. New York: Oxford University Press, Inc.

Leech, G. (2011). Prinsip-prinsip Pragmatik. Terjemahan oleh Oka, M.D.D. Jakarta, Universitas Indonesia (UIPress).

Rohmadi, M. (2010). Pragmatik: Teori dan Analisis. Surakarta: Yuma Pustaka.

(2004). Pragmatik: Teori dan Analisis. Yogyakarta: Lingkar Media.

Sulistyo, E.T. (2013). Pragmatik: Satuan Kajian Awal. Surakarta: UNS Press.

Wright, R.A. (1975). "Meaning $n n$ and Coversational Implicature", Cole and Morgan, Syntax and Semantics Vol. 3: Speech Act. New York: Academf Press.

Yule, G. (1996). Pragmatics. Oxford: Oxford University Press. (1996). Pragmatik. Terj. Indah Fajar Wahyuni. Yogyakarta: Pustaka Pelajar.

Wijana, I.D.P. (1996). Dasar-dasar Pragmatik. Yogyakarta: Andi Offset. 
(2003). Kartun Studi

Tentang Permainan Bahasa.

Jogjakarta: Ombak.

BASASTRA Jurnal Bahasa, Sastra, dan Pengajarannya

Volume 8 Nomor 2, Oktober 2020, P-ISSN 2302-6405, E-ISSN 2714-9765 